\title{
A Mixed Method Study of the Relationship between EFL Teachers' Job Satisfaction and Job Performance in Iran
}

\author{
Afshin Rezaee \\ Ph.D. Candidate, Language Department, Chabahar Maritime University, Iran, \\ afshinrezaee50@gmail.com
}

\section{Hoshang Khoshsima}

Assoc. Prof., corresponding author, Language Department, Chabahar Maritime University, Iran, khoshsima2002@yahoo.com

\section{Esmail Zare-Bahtash}

Assoc. Prof., Language Department, Chabahar Maritime University, Iran, behtash@cmu.ac.ir

\author{
Abdullah Sarani \\ Assoc. Prof., Language Department, University of Sistan and Baluchestan, Iran, \\ sarani_ling@hamoon.usb.ac.ir
}

In the Iranian context, the contribution that job satisfaction might have on English Foreign Language (EFL) teachers' job performance has largely remained unexplored. The current mixed-method study, hence, aims to investigate the possible relationship between EFL teachers' job satisfaction and job performance. For this aim, a total of 440 EFL male and female teachers were selected using stratified random sampling from state schools and private language schools in Tehran, Isfahan, Arak, and Lorestan Provinces. They responded two questionnaires, one assessing the teachers' job satisfaction and the second gauging the teachers' job performance. To triangulate the data gathered from the questionnaires, semi-structured interviews were administered with 40 participants. The collected data were analyzed through running Pearson correlation analysis, multiple regression analysis, and thematic analysis. Results revealed that there exists a moderate positive correlation between the EFL teachers' job satisfaction and their job performance. In addition, it was found that dimensions of pay and benefits, contingent reward, work itself, supervision, and advancement/promotion appeared to be significant predictors of EFL teachers' job performance.

Keywords: job satisfaction, job performance, English teachers, mixed methods study, EFL

Citation: Rezaee, A., Khoshsima, H., Bahtash, E. Z., \& Sarani, A. (2018). A Mixed Method Study of the Relationship between EFL Teachers' Job Satisfaction and Job Performance in Iran. International Journal of Instruction, 11(4), 391-408. https://doi.org/10.12973/iji.2018.11425a 


\section{INTRODUCTION}

Teachers should be regarded as the most important group of professionals for securing the future of a nation. High quality education and successful reforms of educational systems are the result of well-trained, motivated, committed, and satisfied teachers (Nguni, 2005). Masanja (2013) opines that teachers' job satisfaction is a vital factor for any educational organization to be effective in terms of performance and progress. In actuality, job satisfaction is a primary indicator of teachers' performance concerning teaching and other routine responsibilities. The study of teachers' job satisfaction and job performance in teaching has become imperative for the Ministry of Education, administrators, academicians, and school heads at large scale (Masanja, 2013). Attempts to enhance performance in schools are more meaningful if the dimension of teachers' job satisfaction can be seriously taken into account. In general terms, it seems reasonable to argue that when employees in an organization are satisfied, they will render services to the employer and customers very efficiently and effectively (Mbua, 2003).

In the literature, diverse definitions for job satisfaction have been presented. Job satisfaction has been diversely perceived in terms of concept, values, belief, and interest. According to Badreya (2010), job satisfaction is a complex concept which is related to multiple factors. In fact, it is an attitude toward one's work and the related emotions, beliefs, organizational environment, and motivation (Jex \& Britt, 2008). It illustrates why employees behave as they do toward accomplishing personal and organizational goals. In sum, according to Robbins (2010), job satisfaction can be defined as an attitude or feeling about the job itself. In other words, job satisfaction is connected to how people feel about their jobs and their different aspects.

An employee's job satisfaction can be affective and cognitive. Affective job satisfaction is the extent of pleasurable emotional feelings that an individual has about diverse dimensions of his/her job situation. On the other hand, cognitive job satisfaction is the extent of an employee's perception, feelings and responses, with particular aspects of their jobs, such as pay, pension arrangements, working hours and numerous other aspects of their jobs (Kosi, Sulemana, Boateng \& Mensah, 2015). Research findings have reported a number of factors in relation to job satisfaction. These factors include individual factors such as age, gender, education level, and marital status as well as environmental factors such as salary, benefits, promotion, nature of work and supervision. Demographic characteristics define individuals even before entrance into the job and subsequently make variations in job satisfaction across subgroups (Ahmad, Ing, \& Bujang, 2014).

One of the first and most comprehensive model on job satisfaction was developed by Hackman and Oldham (1976). Based on their model, employees collect information about the job, the workplace and the organization and cognitively assess these elements in order to determine the level of satisfaction (Jex \& Britt, 2008). It was suggested that five job characteristics, including skill variety, task identity, task significance, autonomy, and feedback are the crucial factors for job satisfaction. Indeed, it was argued that jobs can be analyzed for their motivating potential by using those five dimensions, 
and can then be redesigned in order to eliminate their dissatisfying aspects. In general, the development of the job characteristics model was built upon the premise that specific core characteristics must exist in work settings so as to create job outcomes of high job satisfaction, high performance, and low employee turnover (Hackman, 1980).

As noted earlier, attainment of a high level of performance through productivity and efficiency has always been an organizational goal of high priority. In order to do that, a highly satisfied work staff is a cardinal necessity to achieve more productive performance in an organization. Job performance is conceptualized simply in output terms as the achievement of quantified objectives. But performance is a matter not only in what people achieve but how they achieve it. According to Kohli and Deb (2008), performance is a behavior or action that is relevant for the achievement of organization's goals and that can be measured in terms of the level of proficiency or contribution to goals that are represented by a particular action or set of actions. Armstrong (2006) considered job performance as the accomplishment, execution, carrying out, and working out of anything ordered or undertaken. He sees that high performance results from appropriate behaviour, especially discretionary behavior, and the effective use of knowledge, skills and competencies. Rashidpoor (2000) comments further that job performance is a set of behavior and actions which a person shows in relation to his/her job. In other words, it is the amount of efficiency gained due to the person's job type (training, producing or servicing).

Similarly, George and Jones (2005) maintain that the level of performance is an evaluation of the results of a person's work behaviour. This involves determining how well or poorly a person performed to accomplish a task. In the context of this study, 'job performance' is defined as a function of how the content of the school's work is effectively accomplished by a teacher. It refers to the actions of the teacher in performing certain jobs or duties in the school system. Furthermore, teacher job performance may be perceived as the willingness of teachers to fulfil the work place tasks and responsibilities for the success of their respective schools.

Job performance is a critical antecedent of performance management. A job consists of a number of inter-related tasks, duties, and responsibilities which a job holder needs to carry out, whereas performance is a behavior or action that is relevant for the organization's goals and that can be measured in terms of the level of proficiency or contribution to goals that are represented by a particular action or set of actions (Faiborother, 2008). This implies that job performance involves certain functional as well as behavioral competencies. Kohli and Deb (2008) assert that a number of factors tend to impact job performance, including knowledge, motivation, feedback, leadership, and personality.

The linkage between job satisfaction and job performance has been critically examined in a variety of organizational settings (Judge, Thoresen, Bono \& Patton, 2001). Overall, the results are inconclusive. Some studies found that there is not much relationship between job satisfaction and job performance (Iaffaldano \& Muchinsky, 1985; Kohli \& Deb, 2008). On the other hand, other analyses of job satisfaction literature have concluded that job satisfaction and job performance are related (Mlyyuka, 2015; 
Ogundele \& Olarewaju, 2014). Indeed, interest in the topic continues to be written about to date. A common assumption among managers has been that employees who are more satisfied in their work tend to be more productive. The question at hand is whether satisfied employees really work harder. If they do, is it because they are satisfied or vice versa?

It seems necessary to conduct a study to enable policy makers in the Ministry of Education in Iran to enhance their insights in plans that promote job satisfaction and job performance among EFL teachers. As it is clear-cut, teachers play a very significant role in the education sector; thus investigating the dimensions that are related to their job satisfaction and performance is essential. In line with this significance, it was aimed to cast light on the possible correlation between the Iranian EFL teachers' job satisfaction and job performance in a mixed method study.

\section{EMPIRICAL STUDIES}

In this part, some of the studies related to the current research are critically examined. In one of the early studies, Ostroff (1992) explored the relationship between teachers' job satisfaction and organizational performance using the data collected from 13, 808 junior and senior high school teachers. He found a strong relationship between teachers' job satisfaction and their job performance at the organizational level. He also found that satisfaction and other job-related attitudes, including commitment, adjustment, and psychological stress are highly correlated with school effectiveness.

In another study, Peng (2014) examined the relationship between job satisfaction of Taiwanese university librarians and their job performance. The findings revealed that both intrinsic and extrinsic job satisfaction contributed to the participants' expected level of task performance and contextual performance (or job performance as a single latent variable). However, she found that the effect of intrinsic job satisfaction on job performance was greater in comparison with extrinsic satisfaction. Thus, she argued that the idea of offering intangible rewards to those working in service industries in the nonprofit sector with lower wages might be an effective one, but in careers such as librarianship, intrinsic motivation has a more important role and contributes more to job performance. The problem with this study was that it could not disclose the reasons behind the findings.

Imran, Arif, Cheema, and Azeem, (2014) aimed at investigating the relationship between job satisfaction, job performance, attitude towards work, and organizational commitment in teaching staff in Pakistan. The sample of the study comprised of 200 employees among teaching staff selected through random sampling method. Their results indicated that there was a strong positive relationship between job satisfaction and job performance as well as a significant positive linkage between organizational job performance and attitude toward the work.

Finally, in the Iranian context, Soodmand Afshar and Doosti (2016) conducted a study investigating the differences between satisfied and dissatisfied Iranian junior secondary school teachers in terms of their job performance from the teachers and students' perspectives. 64 Iranian English teachers and 1774 of their students were selected. The 
results indicated that satisfied teachers significantly differed from their dissatisfied counterparts in terms of their job performance. The findings also showed a significant difference between the students' evaluation of their teachers' job performance compared to the teachers' self-evaluation of their own job performance.

It seems that many factors influence the EFL teachers' job performance in Iran. A key factor and one that has remained largely unexplored in the Iranian context is EFL teacher' job satisfaction. Hence, it is necessary to explore the possible contribution that job satisfaction has on the job performance of the EFL teachers and to take practical steps to improve the EFL teachers' job performance by honing their job satisfaction. However, as can be seen from the presented studies, it can be inferred that there has been a paucity of a nation-wide study to explore the contribution of job satisfaction to job performance in second language education in the Iranian EFL context. Therefore, the current mixed method study aims to cast lights on the possible relationship between EFL teachers' job satisfaction and job performance by answering the following research questions:

1. Is there any significant relationship between Iranian EFL teachers' job satisfaction and job performance?

2. Which job satisfaction factors determine job performance of EFL teachers?

3. In which ways can job satisfaction affect job performance from the EFL teachers' perspectives?

\section{METHOD}

\section{Design}

The current research study in terms of design can be considered as mixed method approach, since the required data were collected through distributing some questionnaires and administering semi-structured interviews. According to Mackey and Gass (2016), by merging both quantitative and qualitative research, the researchers can obtain a deep understanding about the research topic. One of the distinguishing factors of mixed method study is triangulation in which the researchers are able to identify aspects of a phenomenon more accurately by approaching it from different vantage points using different methods and techniques. Hence, to get more comprehensive understandings in relation to the linkage between EFL teachers' job satisfaction and job performance, a mixed method approach was employed.

\section{Participants}

In the present investigation, the sample was selected from various state school and private language schools in Tehran, Isfahan, Arak, and Lorestan Provinces in Iran. The sample consisted of a total 440 EFL male and female teachers, 230 from private schools and 210 from state schools. Great care was exercised to select a representative sample of both groups of teachers using proportional stratified random sampling. Due to the logistical limitations related to recruiting a homogeneous sample, the participants' age, qualification, and years of experience were not controlled. The participation was voluntary and the participants' identity was remained anonymous and they were kept 
informed about the findings of the research. It is worth mentioning that in the pilot study, run to measure the reliability and validity of the instruments, the questionnaires were administered to 40 EFL teachers.

\section{Instruments}

The required data were gathered using the following instruments. The data of the participants' job satisfaction were collected utilizing job satisfaction questionnaire developed and validated by Spector (1985). It contains 36 statements regarding teachers' job satisfaction dimensions. In fact, the questionnaire measures diverse factors that may affect teachers' job satisfaction, including supervision, colleagues and communication, working conditions, pay and benefits, work itself and operating procedures, advancement/promotion, and contingent rewards. For answers to the statements of the questionnaire, a Likert-type scale including expressions with five intervals were used. It is categorized as: (1) Highly Dissatisfied, (2) Dissatisfied, (3) Undecided, (4) Satisfied, and (5) Highly Satisfied.

In order to obtain the required data regarding the participants' job performance, EFL teachers' job performance questionnaire, developed and validated by Moafian and Pishghadam (2009), were administered. The questionnaire was comprised of 49 items requiring English teachers to evaluate their job performance based on a five-point Likert scale ranging from completely disagree (1) to completely agree (5). The questionnaire gauges twelve factors concerning the characteristics of successful English teachers, including teaching accountability, interpersonal relationship, attention to all, examination, commitment, learning boosters, creating a sense of competence, teaching boosters, physical and emotional acceptance, empathy, class attendance, and dynamism.

The worthy point to bear in mind is that the questionnaires were piloted on a sample of 40 EFL teachers to estimate their reliability and validity so that they can be appropriate for the current study purposes. At first, the questionnaires were translated into Persian by an expert in translation in order to avoid potential misunderstandings on behalf of the participants. Internal consistency of the questionnaires were measured through Cronbach's alpha. Reliability for job satisfaction questionnaire (0.72) and EFL teachers' job performance questionnaire (0.92) were calculated, in turn. Based on the participants' responses, some of the statements were revised and modified. Next, regarding the face and content validity, they were given to three well-experienced university professors who have been teaching English courses at public universities over ten years to evaluate and comment on the face and content of the instruments. Totally, the professors confirmed that the instruments can be used for the present study though they commented some points and modifications on the statements. Finally, to generate evidence to construct validity of the instruments, factorial analysis of variance was carried out. In fact, the job satisfaction questionnaire and the EFL job performance questionnaire were subjected to exploratory factor analysis. In sum, the exploratory factor analyses showed that data loaded well on the intended number of factors. That is, the items had at least 0.30 minimum size for the factor load of the relevant item and it was concluded that they could be included in the final version of the instruments. 
Furthermore, semi-structured interviews in conjunction with items in the questionnaires were conducted after administering the questionnaires for 40 participants. The participants were selected using stratified random sampling among the participants who fill out the questionnaires. That is, 20 male teachers and 20 female teachers from state schools and private language schools were chosen. The interview not only can measure the accuracy of the obtained results of the qualitative part, but also can reveal those issues that might not be well-captured by the questionnaires (Mackey \& Gass, 2016). In actuality, to triangulate the data and to make more in-depth interpretations of the data obtained from the Likert-scale questionnaire, semi-structured interviews were administered. Before an interview began, the interviewee was informed about the research topic and he/she was assured that his or her responses to the interview questions would remain confidential. It should be noted that the interviews were run in Persian so that the teachers could express their ideas with greater ease. The participants' responses were carefully recorded by a voice recorder to be meticulously analyzed and transcribed later. That is, the transcripts were independently read some times so that the researchers could make sense of them and extract the main themes.

\section{Data Collection Procedures}

As stated earlier, a mixed method study was designed and conducted to reach the desired aims. The following steps were followed, in turn. First, a pilot study of the questionnaires was conducted to examine the consistency and accuracy of the instruments in wording, content, question sequencing and bias. In fact, the aims were to test the relevance of the instruments to the setting wherein the language teachers were employed. Second, some semi-structured interviews were conducted with several language teachers after the pilot study to ascertain that all of the statements were understandable. The next stage was the administration of the adapted questionnaires to the selected sample. Job satisfaction questionnaire and EFL teachers' job performance questionnaire were given to the participating teachers and they were asked to fill out the items as accurately as possible. The participants were given enough time to answer the items in a relaxed climate. Finally, in order not to jeopardize the study's findings by exclusive reliance on one single type of data, 40 teachers were invited to take part in the semi-structured interviews. Some questions accompanying the questionnaires' items were quested to the participants. The responses were recorded through a voice-reorder carefully to be meticulously analyzed later by the researchers.

\section{Data Analysis Procedures}

Since the current study gathered both qualitative and quantitative data, the analysis processes were also governed by the two approaches. In the quantitative section, in order to provide answers to the first two research questions, common descriptive statistics as well as the inferential statistical methods, including Pearson correlation analysis and multiple regression analysis were run using SPSS version 23. In fact, to inspect the correlation between the EFL teachers' job satisfaction and their job performance Pearson correlation analysis was used. Further, multiple regression analysis was utilized to perceive how much of variance in the EFL teacher's job performance can be explained by the dimensions of job satisfaction. Regarding the qualitative data, the 
EFL teachers' accounts were used to form patterns and categorize the major themes (Strauss \& Corbin, 1998). The current study, in fact, employed content analysis to analyze the qualitative data gathered through semi-structured interviews. To this aim, the content of the interviews was examined carefully and themes were identified and presented.

\section{FINDINGS}

In the present section, the results for each question are reported in detail.

\section{Results of Normality of the Data}

In order to examine if the data meet the requirement of parametric tests, the normality assumption was checked out using Kolmogorov-Smirnov test. Concerning the normality of the collected data from the job satisfaction scale, the findings revealed that since the calculated $\mathrm{p}(0.62)$ was more than the significance level $(0.05)$, it was concluded that the data on the job satisfaction scale are normal. Concerning the sub-components of the job satisfaction scale, the calculated results are supervision $(\mathrm{p}=0.58)$, pay and benefits $(\mathrm{p}=$ $0.50)$, promotion and advancement $(\mathrm{p}=0.64)$, contingent rewards $(\mathrm{p}=0.31)$, colleagues and communication $(\mathrm{p}=0.13)$, work itself $(\mathrm{p}=0.39)$, work conditions and operating procedures $(\mathrm{p}=0.64)$ which were all above the significance level.

Next, to examine if the data collected from the EFL teachers' job performance questionnaire were normal, another Kolmogorov-Smirnov test was employed. Since the calculated $p$ (0.314) was more than the significance level $(0.05)$, it was deduced that the data collected from the job performance questionnaire had the acceptable normality. In relation to the sub-components of the job performance scale, since the calculated ps, accountability $(\mathrm{p}=0.119)$, interpersonal relationship $(\mathrm{p}=0.073)$, attention to all $(\mathrm{p}=$ $0.400)$, examination $(\mathrm{p}=0.151)$, commitment $(\mathrm{p}=0.114)$, learning boasters $(\mathrm{p}=$ $0.203)$, sense of competence $(\mathrm{p}=0.203)$, teaching boosters $(\mathrm{p}=0.400)$, attendance $(\mathrm{p}=$ $0.097)$, dynamism $(\mathrm{p}=0.400)$, empathy $(\mathrm{p}=0.232)$, emotional acceptance $(\mathrm{p}=0.127)$, were more than the significance level, it was concluded that the data are normal.

\section{Results for the First Research Question}

The first research question explored if there was any meaningful relationship between the EFL teachers' job satisfaction and their job performance in Iran. Before running the Pearson Correlation, the descriptive statistics of job satisfaction and job performance were calculated and reported in Table 1. As seen, for the EFL teachers' job satisfaction, M (79.90) and SD (15.54), and job performance, M (132.02) and SD (22.34) were calculated, respectively.

Table 1

Descriptive statistics of the EFL teachers' job satisfaction questionnaire and job performance questionnaire

\begin{tabular}{llll}
\hline & $\mathrm{N}$ & $\mathrm{M}$ & $\mathrm{SD}$ \\
\hline Job satisfaction & 440 & 79.90 & 15.54 \\
\hline Job performance & 440 & 132.02 & 22.34 \\
\hline
\end{tabular}


Table 2 presents the relationship between the participating teachers' job satisfaction and their job performance.

Table 2

The correlation between EFL teachers' job satisfaction and their job performance Correlations

\begin{tabular}{lll}
\hline & & Job Performance \\
\hline \multirow{2}{*}{ Job } & Pearson Correlation & $.401^{* *}$ \\
Satisfaction & Sig. (2-tailed) & .000 \\
& N & 440 \\
\hline
\end{tabular}

**. Correlation is significant at the 0.01 level (2-tailed).

As observed, the results of the Pearson correlation test indicate that there exists a moderate meaningful correlation between the job satisfaction and job performance with the coefficient of $40.1 \%(\mathrm{r}=0.401, \mathrm{Sig}<0.01, \mathrm{~N}=440)$. It means that the more language teachers are satisfied with their job, the more effective performance they have in English teaching.

\section{Results for the Second Research Question}

Another research question dealt with how much of the variation in the EFL teachers' job performance could be attributed to factors composing the job satisfaction. The multiple regression analysis was run to assess the influence of the job satisfaction factors on the participants' job performance.

Table 3

The multiple regression analysis for verifying the effects of EFL teachers' job satisfaction dimensions on job performance

\begin{tabular}{llllllll}
\hline Model & Sum of Squares & df & Mean Square & F & Sig. & $\mathrm{R}^{2}$ & $\mathrm{R}^{2}$ \\
\hline Regression & 52911.189 & 5 & 10582.238 & 27.644 & 000 & .0 .24 & 0.23 \\
\hline Residual & 166136.584 & 434 & 382.803 & & & & \\
\hline Total & 219047 & 439 & & & & \\
\hline
\end{tabular}

As seen in Table 3, the examination of meaningfulness based on ANOVA analysis reveals that the regression analysis for this question is meaningful $(\mathrm{F}=27.644$, $\mathrm{Sig}=$ $0.001)$. In the current analysis, since the value of $R^{2}(0.24)$ is significant, it can be concluded that the dimensions of the job satisfaction have meaningful impact on the EFL teachers' job performance. The next step is to determine the factors which have the highest impact on job performance in the EFL teachers. 
Table 4

The multiple regression analysis for EFL teachers' job satisfaction dimensions

\begin{tabular}{|c|c|c|c|c|c|}
\hline & $\begin{array}{l}\text { Unst } \\
\text { Coef }\end{array}$ & ized & $\begin{array}{l}\text { Standardized } \\
\text { Coefficients }\end{array}$ & & \\
\hline Dimensions & $\overline{\mathrm{B}}$ & Std. Error & Beta & $\mathrm{t}$ & Sig. \\
\hline (Constant) & 9.04 & 4.96 & & 18.21 & .001 \\
\hline Pay and Benefits & 2.67 & .49 & .30 & 5.42 & .001 \\
\hline Contingent rewards & 2.10 & .44 & .28 & 4.74 & .001 \\
\hline Work conditions/Operating principles & 1.38 & .32 & .24 & 4.20 & .001 \\
\hline Supervision & 1.35 & .43 & .17 & 3.09 & .001 \\
\hline Advancement/Promotion & .96 & .38 & .14 & 2.50 & .001 \\
\hline
\end{tabular}

Table 4 shows the job satisfaction factors that influence the EFL teachers' job performance. As $\mathrm{R}^{2}$ coefficient displays, $24 \%$ of the variance in the EFL teachers' job performance can be accounted for by the job satisfaction dimensions. The regression model indicates that the impact of the job satisfaction factors on job performance is valid (with $\mathrm{F}=9.04 ; \mathrm{p}=4.96$ ). According to beta values, the EFL teachers' job satisfaction is mostly affected by pay and benefits $(\beta=30, p=0.5 .42)$, contingent reward $(\beta=0.28, p=4.47)$, work conditions and operating principles $(\beta=0.24, p=$ $4.20)$, supervision $(\beta=0.17, p=3.09)$, advancement/promotion $(\beta=0.14, p=2.50)$. That is, pay and benefits, contingent rewards, work itself, supervision, advancement/promotion have the highest influence on job performance of the participants, in order. It should be highlighted that colleagues and communication and work itself dimension do not have a remarkable effect on the participants' job performance.

\section{Results for the Third Research Question}

One part of the current study was concerned with the influences of the EFL teachers' job satisfaction on the job performance. Indeed, it was investigated to reveal in which ways the job satisfaction can affect job performance from the EFL teachers' perspectives. In responding to this question, because of space limitation, the words of only five participants will be presented. For example, one female teacher at a private language school commented that:

"I think the effects of teachers' job satisfaction on job performance is clear. I mean, when you are not satisfied with your job, you cannot truly do your responsibilities. For example, when you teach in an institute where the principle doesn't have a degree in TEFL and doesn't have a correct understanding about English education, when you work a lot and you don't earn high, when you are hardworking and the promotion is not really equitable, you cannot teach and perform in an effective way."

She added more that:

"I think that the underlying reasons of teachers' dissatisfaction should be removed. In my eyes, to solve the dilemma, the payment should be increased, the promotions and 
rewards should be raised, and the language schools should be managed by qualified principals. I really wish that these problems can be removed and I can teach English with pleasure."

One male teacher in a state school remarked that:

"Since I am not satisfied with the current conditions in my job, I cannot enhance my work effectiveness though I would like to do my duties well. Honestly, I don't feel satisfied with my occupation and this dissatisfaction has negatively influenced my organizational performance. For instance, since the salary system in the Ministry of Education is really unfair, it has made me lose my motivation and courage to improve my career performance, to enhance my professional knowledge, and to assign required more time to my students' educational problems".

He added further that:

"The education system, as you know, revolves around political than educational issues. I mean, the politics is content and the education is margin. If fact, most of the managers at diverse levels are selected according to political mafia. All people know that factionalism have dragged all the sectors of the education into corruption. In that demotivating climate there remains no motivation and interest to make improved job performance. Working condition, I feel, should be charming and facilitative to make the language teachers feel satisfied and, consequently, do their responsibilities efficiently".

Regarding the influences of job satisfaction on job performance, a male teacher in Iran Language Institute (ILI) commented that:

"To me, working in ILI is not interesting and enjoyable. I have to teach a couple of books in a semester and to run large classes. Instead, the salary that I earn is not really enough to meet the ends of my life. The promotion system is not working fairly. I mean, there is not worthy advancement in my job. Truly speaking, I'm not satisfied with the working conditions where you are obliged to act as robot and follow the rules imposed on you by the ILI officials",

He stated further that:

"It is clear-cut that job satisfaction and motivation can impact English teachers' job effectiveness. If the officials of ILI take some steps to increase the job satisfaction among instructors, to be sure, the teachers' organizational performance gets improved soon. Put it in a nutshell, there is a mutual relationship between employees' job satisfaction and job performance. They rise hand in hand together".

A female teacher in a state school answered the question in relation to the effects of job satisfaction on her job performance in this way:

"Where you are working in a system which is top-down. By top-down, I mean, I am obliged to pursue the curricula which is written and sent to us by the policy-makers in Teharn. I don't have any freedom in my job and, therefore, I don't enjoy English 
teaching. More importantly, since I cannot employ my creativity in my career, not only is it boring to me but it also makes me not do the duties well".

She also looked at the issue in a social perspective:

"I think since my job is not appraised and valued by the government and society, I am not willing to put my primary time and energy in education system. That is to say, I have lost my value and position in the society. Therefore, I am not satisfied with my job and, accordingly, I am not functioning well. In fact, I look at English teaching as a second job".

At last, a female teacher in a state school noted that:

"I do my best to teach English in high quality. However, it should be said that there are some big drawbacks in the education system which has made me feel dissatisfied with my job. The teachers who feel really committed and perform their job well, they are not appraised by the Ministry of Education. This has really negatively affected my job performance. When a supervisor observes and evaluates your job, she doesn't pay attention to the quality of your performance. I mean, the qualified and disqualified teachers are seen by the same eyes."

She added more that:

"I think one of the major reasons of dissatisfaction and poor performance among Iranian language teachers traces back to the fact that the students no longer are ready and eager to learn. I mean, they do not put the educational affairs before the other affairs such as playing with cell phone. In brief, I strongly believe that the problems making the teachers feel dissatisfied should be removed if the aim is to improve the quality of education by means of the teachers."

Overall, it can be deduced from the words of the participants that the performance of the Iranian language teachers have been negatively affected by their job satisfaction.

\section{DISCUSSION}

In the discussion part, the findings are discussed, the possible reasons behind the results are presented, and finally, the results are compared and contrasted with some relevant previous studies. The first research question examined whether there was any significant relationship between the EFL teachers' job satisfaction and job performance. Running Pearson correlational analysis indicated a meaningful moderate correlation between the job satisfaction of the EFL teachers and job performance. As shown above, the value of coefficient $(r=0.401, \mathrm{Sig}<0.01, \mathrm{~N}=440)$ revealed that the relationship between the two variables is, to some extent, positive and significant. According to the findings, it may be claimed that the EFL teachers who are satisfied with their job perform more effectively and those who feel dissatisfied do not act well.

The possible reason behind the findings may be ascribed to the fact that there is a cause and effect relationship between EFL teachers' job satisfaction and job performance. It is not rational to expect that the teachers act functionally, when they are not motivated and 
satisfied with their job. Attempts to improve performance in schools will be more meaningful if the aspects of teachers' job satisfaction is seriously taken on board. It is an undeniable truth that if teachers in an educational organization are motivated, they will perform more efficiently and effectively (Mbua, 2003). When serious and constructive steps can be taken by the government to improve teachers' job satisfaction, make regular and fair salary payments for teachers, provide proper housing for teachers, and enhance teaching facilities, it can be suggested that the teachers can perform their responsibilities effectively. In sum, it can be assumed that EFL teachers' job satisfaction leads to improved performance. That is, when English teachers are contented with their job, the level of job performance increases when other factors remain constant.

The study lends support to Ostroff's (1992) finding that there is a strong relationship between job satisfaction and job performance at the organizational level. The results of this study are also in line with those of Fernet, Austin, Robert, and Vallerand (2012) who found that work motivation played a significant role in employee functioning. They argued, indeed, "by promoting optimal motivation, schools and other organizations could benefit from additional strategies not only to attract dedicated employees but also to sustain their commitment and psychological health" (p. 226). In addition, the results of the current study are in accordance with Imran, Arif, Cheema, and Azeem's (2014) study investigating the relationship between job satisfaction, job performance, attitude towards work, and organizational commitment in teaching staff in Pakistan. Their results indicated that there was a strong positive relationship between job satisfaction and performance as well as there existed a significant positive linkage between organizational job performance and attitude toward the work. Considering the results of this study, which included a large sample of EFL teachers, we were convinced to conclude that job satisfaction/dissatisfaction plays a significant role in English teachers' job performance in Iran.

Another research question wanted to unveil which job satisfaction factors have the most explanatory power to constitute variations in EFL teachers' job performance. In answering this research question, we drew on the results from the multiple regression analysis. According to the findings offered in the previous section, it was revealed that the EFL teachers' performance is mostly affected by pay and benefits, contingent reward, work conditions and operating principles, supervision, and advancement/promotion. However, it was found that colleagues and communication and work itself dimensions did not have a remarkable effect on the job performance of the participants.

It is logical to argue that the lack of salary satisfaction decreases job satisfaction, job performance, motivation and increases absenteeism and turnover intentions (Stanley, 2005). Moorhead and Griffen (2007) contend that equitable and fare salary treatments among employees along with ensuring job security can promote job satisfaction and job performance. Concerning the supervision facet, the productivity and performance can be improved with qualified managerial actions and supervision. Indeed, Sajuyigbe, Olaoye and Adeyemi (2013) noted that recognition of the achievements by the principals can lead to higher job satisfaction and improved job performance. Working conditions and 
operating principles can likely have a significant impact on job satisfaction and performance when, for example, the working conditions are either extremely good or extremely poor, the performance will be affected negatively. It seems that teachers derive satisfaction from teaching when the conditions are interesting and challenging. Robbins (2003) argues that under conditions of moderate challenge, most employees will experience pleasure and satisfaction. Finally, teachers expect their jobs to provide them with opportunities to be promoted to new and challenging positions. When the promotion system is not fair and equitable, it may cause the hard-working teachers to lose their courage to continue on the right road.

The results of the current study are in line with Kohli and Deb's (2008) findings that factors such as values, attitudes, perceptions, leadership, competencies, motivation, and feedback of employer on employee performance have great impact on individual employee's job performance. Further, the findings back up the study done by Usman (2004) revealing that there is a statistical significant relationship between teachers' job satisfaction and job performance. The regression results, further, indicated that living and working conditions as well as supervision such as by school heads have greater influence on teachers' job performance than the other predictors. Overall, it can be deduced that the more satisfied the EFL teachers are with their job, the improved performance they will have in school.

The final research question explored how the teachers' job satisfaction can affect their job performance from the EFL teachers' perspective. Put it in other words, it was searched for the effects of the job satisfaction on the EFL teachers' job performance from a qualitative perspective. Based on the data collected from the interviews, it can be reasoned that the job performance of language teachers has negatively been affected by the job satisfaction. That is, since the EFL teachers are not satisfied, they cannot perform well in the teaching profession in the EFL context of Iran.

One possible reason for the dissatisfaction and, accordingly, the weak performance of the Iranian EFL teachers may be related to the working environment in which they are teaching. In line with this proposal, De Nobile and McComic (2008) opine that working conditions have a significant positive relationship with teachers' job satisfaction, regardless of whether the school is public or private, elementary or secondary. As inferred from the voices of the participants, the efforts of the teachers do not receive enough attention on the part of the officials leading to dissatisfaction and poor performance among the teachers. As it is obvious, appreciation is a fundamental human need. Normally, employees enjoy responding to appreciation expressed through recognition of their good work and it confirms their work is valued (Spector, 2008). Hence, when language teachers and their performance are valued and praised, accordingly, their satisfaction and performance rise, and they are motivated to maintain or improve their good job performance. Another possible explanation for the lack of satisfaction with job in the EFL teachers is germane to feeling that chances for promotion are scarce in the Ministry of Education in Iran. Masanja (2013) is of the opinion that teachers' moral at work will definitely improve, when there exists a framework which clearly stipulates the progression upon completion of specific 
responsibilities. Taken together, there is a cause and effect relationship between job satisfaction and job performance in such a way that the more satisfied a language teacher is, the more effective and efficient performance he/she has in English teaching.

\section{CONCLUSION}

Schools aim to accomplish objectives which have been put up to raise the new generations to get success and happiness. The achievement of these goals is executed by the teachers worked in the schools. In reality, the education system can reach its ultimate objectives if the teachers can perform their job well. One of the factors may impact the job performance of teachers is job satisfaction. Indeed, for the success and survival of any education system job satisfaction is of vital importance. Satisfied teachers are likely the most valuable assets of any growing education system whereas dissatisfied teachers are the biggest liabilities (Soodmand Afshar \& Doosti, 2016). Looking at the available literature reveals that the contributions of job satisfaction to EFL teachers' job performance has remained unexplored in a nation-wide scope in Iran. Therefore, the present study sought out to explore the correlation between EFL teachers' job satisfaction and their job performance in a mixed methods approach in some Provinces in Iran. In sum, the results indicated that there is a moderate meaningful correlation between the EFL teachers' job satisfaction and their job performance. Further, it was unveiled that dimensions of pay and benefits, contingent reward, work itself, supervision, and advancement/promotion appeared to be significant predictors of EFL teachers' job performance. Meanwhile, the findings of the interviews indicated that the job performance of language teachers has negatively been affected by their job satisfaction.

In accordance with the findings, some implications are presented. First, there is an urgent need for serious measures to address the problems of EFL teachers' dissatisfaction so as to enhance their job satisfaction and, accordingly, their job performance. For this to be possible, the government should take up practical steps to include policies that value teachers' effort and reward them according to how they apply their knowledge and competencies for productive activities that are consistent with the schools objectives. The government, in fact, should revise its policies regarding the salary paid to teachers. Second, since the work itself makes a crucial contribution to teachers' job satisfaction, it is necessary for the schools' officials to have an efficient strategy for maintaining and improving EFL teachers' work conditions. Concerning promotions, third, the policy makers of the education should set up a clear system of promotions that is based on qualification, educational advancement, performance and merit. Finally, the government must select the principals and supervisors based on scientific criteria so that they can set the scene for the EFL teachers' higher job satisfaction and improved job performance.

In line with the current study, some recommendations for further research are offered. It is recommended that longitudinal research should be carried out to uncover the effects of job satisfaction on job performance with the cross of time among Iranian English teachers. More studies can also explore the correlation between job satisfaction and job performance among English university teachers. In addition, it is suggested that the 
impacts of job satisfaction and its subcomponents on Iranian language teachers' job motivation, job commitment and job attitude are explored in a mixed method study. In the end, further research can be run to unveil the possible impacts of EFL teacher' satisfaction on their students' satisfaction and performance in English learning in the Iranian context.

\section{REFERENCES}

Ahmad, R.; Ing, H.E.; \& Bujang, S. (2014). Relationship between selected factors of job satisfaction and job performance among workers at Palm Oil Industries in SibuSarawak, Malaysia. International Review of Management and Business Research, 3(3), 1751-1766.

Armstrong, M. (2006). Human resource management practice (10th ed.). London and Philadelphia: Kogan Page.

Badreya, J. (2010). Job satisfaction comparisons among diverse public organization in the UAE. Journal of Management Science and Engineering, 4(3), 60-79.

De Nobile, J., \& McCormick, J. (2008). Job satisfaction of catholic primary school staff: A study of biographical differences. International Journal of Education Management, 27(2), 135-150.

Faiborother, K. (2008). Work Place Dimensions, Stress and Job Satisfaction. Journal of Managerial Psychology, 18(1), 802-818.

Fernet, C.; Austin, S.; Robert, J.; \& Vallerand (2012). The effects of work motivation on employee exhaustion and commitment: An extension of the JD-R model. Work \& Stress, 26(3), 213-229.

George, J. M., \& Jones, G. R. (2005). Understanding and managing organizational behavior (4th ed.). New Jersey: Pearson Education, Inc.

Hackman, J. R., \& Oldham, G. R. (1976). Motivation through the design of work: test of a theory. Organizational Behavior and Human Performance, 16(2), 250-279.

Hackman, R. J. (1980). Work Design. Calcutta: Oxford Book Company.

Iaffaldano, M., \& Muchinsky, P. (1985). Job satisfaction and job performance: A metaanalysis. Psychological Bulletin, 97, 251-273.

Imran, H.; Arif I.; Cheema S.; \& Azeem M. (2014). Relationship between job satisfaction, job performance, attitude towards work, and organizational commitment. Entrepreneurship and Innovation Management Journal, 2(2), 135-144.

Jex, S. \& Britt, T. (2008). Organizational psychology: A scientific-practitioner approach (2nd ed.). New Jersey, U.S.A.: John Wiley \& Sons, Inc.

Kohli, A. and Deb, T. (2008). Performance Management. New Delhi: Oxford University Press. 
Kosi, I.; Sulemana, I.; Boateng, J. S.; \& Mensah, R. (2015). Teacher motivation and job satisfaction on intension to quit: An empirical study in public second cycle schools in Tamale metropolis, Ghana. International Journal of Scientific and Research Publication. 5(5), 1-8.

Mackey, A., \& Gass, S. M. (2016). Second language research: Methodology and design (2end ed.). New York: Routledge.

Masanja, S. (2013). Effects of workplace conditions on primary school teachers' job satisfaction in Tanzania (Unpublished Doctoral thesis). University of Dar es Salaam, Tanzania.

Mbua, F. (2003). Educational administration: Theory and practice. Limbe, South-West Province, U.S.A.: Design House.

Mlyuka, E. E. (2015). The quest for teacher job satisfaction-job performance relationship in Tanzania public primary school: The case of Irigina Region (Unpublished Doctoral Dissertation). Open University: Tanzania.

Moafian, F., \& Pishghadam, R. (2009). Construct validation of a questionnaire on characteristics of successful Iranian EFL teachers. Pazhuhesh-e Zabanha-ye Khareji, $54,127-142$.

Moorhead, G., \& Griffen, R. W. (2007). Organization behaviour managing people and organizations. Shanghai, China: Translation and Printing Services.

Nguni, S. (2005). Effects of transformational leadership on teachers' job satisfaction, organizational commitment and organizational citizenship behaviour in Tanzania schools (Unpublished PhD). Redbud University, Nijmegen Holand.

Ogundele, N., \& Olarewaju, M. (2014). Teachers' job satisfaction and performance of secondary schools in Kwara State. International Journal of Research, 1(11), 1129-1138.

Ostroff, C. (1992). The relationship between satisfaction, attitudes, and performance: An organizational level analysis. Journal of Applied Psychology, 77(6), 963-974.

Peng, Y. P. (2014). Job satisfaction and job performance of university librarians: A disaggregated examination. Library \& Information Science Research, 36, 74-82.

Rashidpoor, M. (2000). Correlation analysis of organizational commitment and job performance of calculating organization personnel. Unpublished MSc. Thesis, Governmental Management Education Center.

Robbins, S. (2003). Organizational behaviour concepts, controversies, application, (8th ed.) New Jersey, U.S.A.: Prentice-Hall International.

Sajuyigbe, A. S.; Olaoye, B. O.; \& Adeyemi, M. A. (2013). Impact of rewards on employees' performance in a selected manufacturing companies in Ibadan. International Journal of Arts and Commerce, 2(2), 25-35. 
Soodmand Afshar, M., \& Doosti, M. (2016). Investigating the impact of job satisfaction/dissatisfaction on Iranian English teachers' job performance. Iranian Journal of Language Teaching Research 4(1), 97-115.

Spector, P. E. (1985). Measurement of human service staff satisfaction: Development of the job satisfaction survey. American Journal of Community Psychology, 13(6), 693713.

Stanley, P. (2005). Variables that contribute to job satisfaction of secondary school assistant principals (Unpublished Ph.D. Dissertation). Virginia Polytechnic Institute and State University, Virginia: U.S.A.

Strauss, A., \& Corbin, J. (1998). Basics of qualitative research. London, U.K.: Sage Publications.

Usman, A. (2004). Relationship between teachers' job satisfaction and job performance in Borno State secondary schools. Unpublished M.A. Thesis, University of Maiduguri, Nigeria.

Azhar M. (2007) Level Of Professionalisme Among Islamic Education Trainees In Practical Teaching (Unpublished Masters thesis). Universiti Teknologi Malaysia, retrieved September 2011 from eprints.utm.my/4276/1/75215.pdf 